\title{
Effect of magnesium carbonate on the uptake of aqueous zinc and lead ions by natural kaolinite and clinoptilolite
}

\author{
T. Shahwan *, B. Zünbül, A.E. Eroğlu, S. Yılmaz \\ Department of Chemistry, Izmir Institute of Technology, Urla 35430, Izmir, Turkey
}

Received 27 August 2004; received in revised form 31 March 2005; accepted 31 May 2005

Available online 28 July 2005

\begin{abstract}
Adsorption behavior of $\mathrm{Zn}^{2+}$ and $\mathrm{Pb}^{2+}$ ions on kaolinite and clinoptilolite, originating from natural resources, was studied as a function of contact time and concentration. $\mathrm{Zn}^{2+}$ and $\mathrm{Pb}^{2+}$ ions are quickly adsorbed on both minerals and the uptake of the latter is more favored. The uptake of both ions was then examined on kaolinite- $\mathrm{MgCO}_{3}$ and clinoptilolite $-\mathrm{MgCO}_{3}$ mixtures over a metal ions range from 1 to $10000 \mathrm{mg} / \mathrm{L}$. The sorption behavior of $\mathrm{Zn}^{2+}$ and $\mathrm{Pb}^{2+}$ on pure $\mathrm{MgCO}_{3}$ was also studied. $\mathrm{MgCO}_{3}$ is much more effective in the retention of $\mathrm{Zn}^{2+}$ and $\mathrm{Pb}^{2+}$ ions, in particular at higher concentrations. The large increase in the retarded amounts of both ions was associated with formation of the hydroxy-carbonate phases; namely hydrozincite for $\mathrm{Zn}^{2+}$, and cerussite and hydrocerussite in the case of $\mathrm{Pb}^{2+}$.
\end{abstract}

(C) 2005 Elsevier B.V. All rights reserved.

Keywords: Kaolinite; Clinoptilolite; $\mathrm{MgCO}_{3}$

\section{Introduction}

The bioavailability and mobility of naturally or anthropogenically released trace metal contaminants, such as $\mathrm{Zn}^{2+}$ and $\mathrm{Pb}^{2+}$, in aquatic, aerial, and soil ecosystems are of great concern from the view point of environmental safety. Metal ions, which are natural constituents of the Earth's crust, can exert beneficial or harmful biological effects on the living organisms. $\mathrm{Zn}^{2+}$ ions are essential for humans, and deficiency

\footnotetext{
* Corresponding author. Tel.: +90 232750 7540; fax: +90 232 7507509.

E-mail address: talalshahwan@iyte.edu.tr (T. Shahwan).
}

states with clinical abnormalities have been identified (Caussy et al., 2003). $\mathrm{Zn}^{2+}$ is commonly found in contaminated soils, sediments, and wastewater and groundwater streams. It accumulates in soils by atmospheric deposition originating from smelting operations and by agricultural applications of sewage sludge and agrochemicals and plays an essential role in cellular systems and enzymes (Nachtegaal and Sparks, 2004). Pb compounds are continuously discharged into the biological environments by various individual and industrial activities (gasoline, batteries, paints, insecticides, pipes, etc.). Due to its potential detriment to the living systems, $\mathrm{Pb}$ is classified at the top of the priority list of the most hazardous sub- 
stances along with $\mathrm{As}, \mathrm{Hg}, \mathrm{C}_{2} \mathrm{H}_{3} \mathrm{Cl}$, and $\mathrm{C}_{6} \mathrm{H}_{6}$ (Godelitsas et al., 2003).

At the interface between aqueous media and soil, adsorption is an important process that can regulate the transport of chemical species through the hydrosphere. In industry, as far as the concentration of waste and the cost of treatment are considered, adsorption is an advantageous treatment method for removal of heavy metal ions from metal contaminated effluents. It was reported that sorption will be established into the aforementioned group of BATNEEC (best available technology not entailing excessive costs) treatment technologies as a standard process (Lehmann et al., 1999).

Kaolinite and clinoptilolite are often present as soil components.. Due to the tight interlayer structure of kaolinite, most adsorption activities occurs along the edges and surfaces of the clay structure (MirandaTrevino and Coles, 2003). Typically, kaolinite has a cation exchange capacity (CEC) of 3 to $15 \mathrm{meq} / 100 \mathrm{~g}$. while values quoted for the specific surface area (SSA) of kaolinite are from 10 to $20 \mathrm{~m}^{2} / \mathrm{g}$ (Coles and Yong, 2002). Clinoptilolite is used in various applications, e.g. as ion exchanger, in gas separation, and removal of $\mathrm{SO}_{2}$ and $\mathrm{NH}_{3}$ (Tanaka et al., 2003). The CEC of clinoptilolite was reported to be 222-238 meq/100 $\mathrm{g}$ with $\mathrm{Na}^{+}$or $\mathrm{K}^{+}$as eluting cation, respectively (Langella et al., 2000).

Carbonate minerals are important constituents of soil and are frequently associated with other soil components like clay minerals, zeolites, and other mineral types, affecting the adsorption properties of these minerals. The presence of $\mathrm{CaCO}_{3}$ in adsorbents was reported to correlate positively with the amount of removed metal ions from solutions (Wenming et al., 2001; Shahwan et al., 2002). $\mathrm{MgCO}_{3}$ is among the most widely spread carbonate minerals in Earth's crust which plays an important role in regulating the aquatic environments as a result of precipitation, dissolution and sorption reactions. Based on a linear free energy correlation model, magnesite was predicted to have the largest trace metal partition coefficients among the carbonate minerals possessing a calcite structure (Wang and $\mathrm{Xu}, 2001$ ).

The aim of this study is to examine the uptake behavior of $\mathrm{Zn}^{2+}$ and $\mathrm{Pb}^{2+}$ by kaolinite and clinoptilolite and to evaluate the effect of $\mathrm{MgCO}_{3}$ on this uptake. So far, several studies were reported in litera- ture regarding different aspects of the adsorption behavior of $\mathrm{Zn}^{2+}$ and $\mathrm{Pb}^{2+}$ by kaolinite and clinoptilolite (e.g. Mier et al., 2001; Mondale et al., 1995; Ouki and Kavannagh, 1997; Ponizovsky and Tsadilas, 2003; Coles and Yong, 2002; Langella et al., 2000; Ikhsan et al., 1999; Hooda and Alloway, 1998; Holm and Zhu, 1994). Our literature survey indicated a scarcity in the available data regarding the uptake of these ions by $\mathrm{MgCO}_{3}$ (e.g. Lehmann et al., 1999).

\section{Experimental}

Kaolinite and clinoptilolite came from Sındırgı and Manisa regions located in the western part of Anatolia. The samples were dry-sieved and the particle size of kaolinite used in this study was $38-75 \mu \mathrm{m}$ while that of clinoptilolite was $75-150 \mu \mathrm{m}$. The particle size of $\mathrm{MgCO}_{3}$ (Fluka Chemika 63032) was 53-300 $\mu \mathrm{m}$. Determination of the BET surface area was achieved by means of a Micrometrics ASAP 2010 instrument using nitrogen at $77 \mathrm{~K}$. The samples were degassed for $3 \mathrm{~h}$ at $353 \mathrm{~K}$.

CEC measurements were carried out by first exposing $1.0 \mathrm{~g}$ samples of kaolinite and clinoptilolite to $100 \mathrm{~mL}$ of fresh $0.5 \mathrm{M} \mathrm{CaCl}_{2}$ solution on a daily basis under continuous mixing. This treatment was repeated three times, then the mineral samples were filtered and carefully washed. The adsorbed $\mathrm{Ca}^{2+}$ ions were successively leached using $100 \mathrm{~mL}$ aliquots of fresh $0.5 \mathrm{BaCl}_{2}$ solution, a process that was repeated four times on a daily basis. The released $\mathrm{Ca}^{2+}$ ions were then analyzed by AAS and ICP-AES.

The adsorption experiments were performed using $50-\mathrm{ml}$ polyethylene tubes. To each tube, $0.50 \mathrm{~g}$ of kaolinite or clinoptilolite were added, followed by the addition of 50.0 $\mathrm{ml}$ of aqueous $\mathrm{Pb}\left(\mathrm{NO}_{3}\right)_{2}$ or $\mathrm{Zn}\left(\mathrm{NO}_{3}\right)_{2}$ solution. In the kinetic studies, the initial concentrations of the solutions were 1,100 , and $1000 \mathrm{mg} / \mathrm{L}$ and the contact periods were $10 \mathrm{~min}, 30 \mathrm{~min}, 2 \mathrm{~h}, 8 \mathrm{~h}, 24 \mathrm{~h}$, and $48 \mathrm{~h}$.

The concentrations of the solutions used to study the effect of $\mathrm{MgCO}_{3}$ on the uptake by kaolinite and clinoptilolite were $1,100,500,3000$, and $10000 \mathrm{mg} / \mathrm{L}$. Appropriate amounts of $\mathrm{MgCO}_{3}$ were mixed with kaolinite or clinoptilolite to yield compositions of $5 \%, 10 \%, 25 \%$, and $60 \%(\mathrm{w} /$ w) of $\mathrm{MgCO}_{3}$. The initial (at the start of mixing) and final (at the end of mixing) $\mathrm{pH}$ values obtained during the adsorption experiments are given in Tables 1 and 2. The speciation of both ions in aqueous media, in the absence of any complexing agent, and at two different concentrations $(100 \mathrm{mg} / \mathrm{L}$ and $10000 \mathrm{mg} / \mathrm{L})$ was analyzed using Visual MINTEQ software. This speciation model was also applied in earlier studies by other authors (e.g. Pierrard et al., 2002; 
Table 1

Initial (at the start of mixing) and final (at the end of mixing) $\mathrm{pH}$ values of $\mathrm{Zn}^{2+}$ and $\mathrm{Pb}^{2+}$ solutions in contact with kaolinite, clinoptilolite, and $\mathrm{MgCO}_{3}$

\begin{tabular}{llllc}
\hline $\begin{array}{l}\text { Cation } \\
\left(\mathrm{M}^{2+}\right)\end{array}$ & $\begin{array}{l}\text { Initial concentration } \\
\mathrm{M}\left(\mathrm{NO}_{3}\right)_{2}(\mathrm{mg} / \mathrm{L})\end{array}$ & Kaolinite & Clinoptilolite & $\mathrm{MgCO}_{3}$ \\
\hline $\mathrm{Zn}^{2+}$ & 1.0 & $7.8-8.9$ & $8.3-8.4$ & $10.1-10.0$ \\
& 100.0 & $6.4-7.1$ & $6.7-7.4$ & $8.1-9.6$ \\
& 500.0 & $5.3-5.9$ & $6.3-7.6$ & $6.7-9.1$ \\
& 3000.0 & $6.5-6.8$ & $6.1-6.3$ & $6.6-7.5$ \\
& 10000.0 & $6.0-6.2$ & $6.0-6.1$ & $6.1-6.3$ \\
$\mathrm{~Pb}^{2+}$ & 1.0 & $7.7-8.0$ & $8.6-8.0$ & $9.9-9.8$ \\
& 100.0 & $6.5-7.1$ & $6.5-7.9$ & $9.6-9.3$ \\
& 500.0 & $5.3-5.9$ & $6.3-7.6$ & $6.3-9.0$ \\
& 3000.0 & $4.8-5.4$ & $4.1-5.0$ & $4.9-8.9$ \\
& 10000.0 & $4.1-4.7$ & $3.9-4.4$ & $4.1-7.7$ \\
\hline
\end{tabular}

Nour El-Dien et al., 1997). The data was generated based on parameters like initial concentration of ions, temperature, $\mathrm{pH}$, and ionic strength, defined in an input file. The results indicated that the principal form of $\mathrm{Pb}$ at $\mathrm{pH} 1-7$ is $\mathrm{Pb}^{2+}$. As the $\mathrm{pH}$ increases beyond 8 , hyroxyl species of $\mathrm{Pb}^{2+}$ are formed; $\mathrm{PbOH}^{+}$and $\mathrm{Pb}_{2} \mathrm{OH}^{3+}$, in addition to higher polycations. As the $\mathrm{pH}$ approaches 12, the major form becomes
$\mathrm{Pb}(\mathrm{OH})_{3}^{-}$together with $\mathrm{Pb}(\mathrm{OH})_{2}$. In the case of $\mathrm{Zn}^{2+}$, the speciation analysis revealed that $\mathrm{Zn}^{2+}$ ions exist up to $\mathrm{pH}$ of 8.. At $\mathrm{pH} 8-11$, the main form becomes $\mathrm{Zn}(\mathrm{OH})_{2}$, and at $\mathrm{pH}>11, \mathrm{Zn}(\mathrm{OH})_{3}^{-}$dominates. Comparing these speciation with the $\mathrm{pH}$ data in Tables 1 and 2, the fraction of hydroxo species of both ions decreases when the initial concentration increases. In order to elucidate the effect of $\mathrm{pH}$ on the morphology of the evolving $\mathrm{Zn}$ - and $\mathrm{Pb}$-carbonate species, separate sets of the experiments with initial concentrations of $10000 \mathrm{mg} / \mathrm{L}$ were performed at initial $\mathrm{pH} 10$. The $\mathrm{pH}$ was adjusted by a $0.1 \mathrm{M} \mathrm{NaOH}$ solution.

The experiments were conducted using the batch method at $25{ }^{\circ} \mathrm{C}$ under atmospheric pressure. The dispersions were shaken for $48 \mathrm{~h}$ (Nuve ST 402 water bath shaker equipped with a microprocessor thermostat). At the end of each mixing period, the samples were filtered and dried at $90{ }^{\circ} \mathrm{C}$. The filtrates were analyzed by flame AAS using a Thermo Elemental SOLAAR M6 Series atomic absorption spectrometer ( $\mathrm{Pb}$ and $\mathrm{Zn}$ hollow cathode lamps) with air-acetylene flame.

XRPD was performed using a Philips X'Pert Pro diffractometer $\left(\mathrm{Cu} \mathrm{K} \mathrm{K}_{\alpha}\right.$ radiation, step size of $\left.0.0202 \theta\right)$. SEM/ EDS characterization was carried out with a Philips XL-30S FEG type instrument. The solid samples were sprinkled onto adhesive carbon tapes supported on metallic disks. EDS

Table 2

Initial (at the start of mixing) and final (at the end of mixing) $\mathrm{pH}$ values of $\mathrm{Zn}^{2+}$ and $\mathrm{Pb}^{2+}$ solutions in contact with kaolinite- $\mathrm{MgCO}$, and clinoptilolite- $\mathrm{MgCO}_{3}$ mixtures

\begin{tabular}{|c|c|c|c|c|c|c|}
\hline \multirow[t]{2}{*}{ Cation } & \multirow[t]{2}{*}{ Initial concentrate $(\mathrm{mg} / \mathrm{L})$} & \multirow[t]{2}{*}{ Mixture } & \multicolumn{4}{|c|}{$\mathrm{MgCO}_{3}($ wt.\%) } \\
\hline & & & 5 & 10 & 25 & 60 \\
\hline \multirow[t]{5}{*}{$\mathrm{Zn}^{2+}$} & 1.0 & \multirow[t]{10}{*}{ Kaolinite- $\mathrm{MgCO}_{3}$} & $9.5-9.7$ & $9.6-9.7$ & $10.1-9.3$ & $10.1-9.8$ \\
\hline & 100.0 & & $7.5-9.1$ & $7.4-9.4$ & $7.2-9.4$ & 7.7-9.4 \\
\hline & 500.0 & & $6.8-9.3$ & $6.8-9.5$ & $6.9-9.4$ & $7.2-9.6$ \\
\hline & 3000.0 & & $6.5-6.8$ & $6.5-5.7$ & $6.6-6.8$ & $6.6-8.7$ \\
\hline & 10000.0 & & $6.0-6.1$ & $6.1-5.9$ & $6.1-6.1$ & $6.1-7.1$ \\
\hline \multirow[t]{5}{*}{$\mathrm{Pb}^{2+}$} & 1.0 & & $9.6-9.2$ & $9.3-9.2$ & $9.8-9.4$ & $9.7-9.7$ \\
\hline & 100.0 & & $6.5-8.5$ & $6.6-8.2$ & $8.2-8.8$ & $9.1-9.4$ \\
\hline & 500.0 & & $5.3-9.3$ & $5.7-9.5$ & $5.8-9.4$ & $6.1-9.6$ \\
\hline & 3000.0 & & $5.0-5.6$ & $5.0-6.6$ & $4.9-8.7$ & $4.9-8.9$ \\
\hline & 10000.0 & & $4.2-4.6$ & $4.0-4.6$ & $4.0-4.9$ & $4.0-5.1$ \\
\hline \multirow[t]{5}{*}{$\mathrm{Zn}^{2+}$} & 1.0 & \multirow[t]{10}{*}{ Clinoptilolite- $\mathrm{MgCO}_{3}$} & $9.5-9.5$ & $9.4-9.5$ & $9.6-9.3$ & $9.9-9.4$ \\
\hline & 100.0 & & $7.2-9.1$ & $7.8-9.3$ & $8.7-9.3$ & $8.1-9.2$ \\
\hline & 500.0 & & $6.3-9.1$ & $6.4-9.1$ & $6.2-9.6$ & $6.6-9.2$ \\
\hline & 3000.0 & & $6.3-6.4$ & $6.4-6.6$ & $6.3-8.3$ & $6.3-8.3$ \\
\hline & 10000.0 & & $6.1-5.9$ & $6.1-5.9$ & $6.2-6.1$ & $6.1-7.2$ \\
\hline \multirow[t]{5}{*}{$\mathrm{Pb}^{2+}$} & 1.0 & & $9.4-8.8$ & $9.3-9.1$ & $9.1-8.9$ & $9.2-9.2$ \\
\hline & 100.0 & & $7.8-9.1$ & $7.6-9.1$ & $9.1-8.7$ & $9.6-9.1$ \\
\hline & 500.0 & & $6.3-9.1$ & $6.4-9.1$ & $6.2-9.6$ & $6.0-9.2$ \\
\hline & 3000.0 & & $4.4-5.1$ & $4.5-8.4$ & $4.1-8.8$ & $5.6-9.2$ \\
\hline & 10000.0 & & $3.9-4.6$ & $3.8-4.8$ & $3.8-5.4$ & $3.7-8.5$ \\
\hline
\end{tabular}

In all cases, $M / V$ ratio is $0.5 \mathrm{~g}$ solid $/ 50 \mathrm{~mL}$ solution. 
elemental analysis was performed at different points on the surface in order to minimize possible anomalies arising from the heterogeneous nature of the analyzed surface.

\section{Results and discussion}

The mineralogical purity of the natural samples of kaolinite and clinoptilolite was tested using XRPD. Kaolinite samples were composed of kaolinite in addition to quartz as the main impurity whereas clinoptilolite appeared to be almost pure. EDS indicated that the average elemental content of kaolinite was $66.8 \% \mathrm{O}, 17.6 \% \mathrm{Si}, 14.1 \% \mathrm{Al}$ in addition to minor quantities of $\mathrm{Na}, \mathrm{K}, \mathrm{Mg}$, and $\mathrm{Ca}$ probably originating from a non-kaolinitic impurity that is below the detection limit of XRPD. The average elemental composition of clinoptilolite was $61.9 \%$ $\mathrm{O}, 23.7 \% \mathrm{Si}, 5.3 \% \mathrm{Al}$, including small amounts of $\mathrm{Na}, \mathrm{K}, \mathrm{Mg}$, and $\mathrm{Ca}$. For $\mathrm{MgCO}_{3}$, the average elemental content was $15.6 \% \mathrm{Mg}, 21.2 \% \mathrm{C}$, and $61.3 \%$ $\mathrm{O}$ in addition to a minor amount of $\mathrm{Ca}$. The EDS values given above represent an average of five data points obtained from random locations on the mineral surface, and correspond to the upper surface ( $\sim 2 \mu \mathrm{m}$ depth). SEM images indicated that the kaolinite particles have well-defined hexagonal plates with edge sizes from 300 to $500 \mathrm{~nm}$. Clinoptilolite seems to be composed of crystals with varying shape and size of several micrometers. $\mathrm{MgCO}_{3}$ was composed mostly of aggregates with variable shapes and sizes and lacked a distinct morphology.

The CEC values for kaolinite and clinoptilolite samples were 21.4 and 192.6 meq $\mathrm{Ca}^{2+} / 100 \mathrm{~g}$ of the mineral. The CEC of the kaolinite applied in our studies appears to be larger than the typical values reported for pure kaolinite being usually within 3-15 $\mathrm{meq} / 100 \mathrm{~g}$ range (Coles and Yong, 2002). This is possibly attributed to the presence of smectite-like impurities, which could enhance the CEC significantly even if present in small amounts. The presence of such an impurity could be responsible for the presence of the exchangeable elements; $\mathrm{Na}, \mathrm{K}, \mathrm{Mg}$, and $\mathrm{Ca}$ - mentioned above - in natural kaolinite. On the other hand, the CEC of clinoptilolite applied in this work seems to be somewhat smaller than typical values reported to vary within $222-238 \mathrm{meq} / 100 \mathrm{~g}$ (Langella et al., 2000). The specific surface area
(BET) of kaolinite is $6.9 \mathrm{~m}^{2} / \mathrm{g}$, of clinoptilolite is $31.7 \mathrm{~m}^{2} / \mathrm{g}$. Surface area determination by BET- $\mathrm{N}_{2}$ was reported to yield lower values as compared to EGME method (Coles and Yong, 2002).

The effect of time of mixing on the adsorption of $\mathrm{Pb}^{2+}$ and $\mathrm{Zn}^{2+}$ kaolinite was studied at room temperature at the initial concentrations of 1,100 , and $1000 \mathrm{mg} / \mathrm{L}$ of the nitrate solutions of both ions. Equilibrium was reached faster at the initial concentrations of 1 and $100 \mathrm{mg} / \mathrm{L}$ than at the $1000 \mathrm{mg} / \mathrm{L}$. Adsorption was faster for kaolinite than for clinoptilolite. The adsorption sites on kaolinite are located mainly on the surface and edge sites of the clay mineral and are more readily accessible than those of clinoptilolite, an important fraction of which is provided by the channels within the structure. Over the entire range of initial concentrations, equilibrium is generally achieved within the first $24 \mathrm{~h}$ of mixing. The further experiments were carried out at this mixing period.

The effect of concentration on the uptake of aqueous $\mathrm{Zn}^{2+}$ and $\mathrm{Pb}^{2+}$ ions by kaolinite and clinoptilolite was investigated at the initial concentrations of $\mathrm{Zn}\left(\mathrm{NO}_{3}\right)_{2}$ and $\mathrm{Pb}\left(\mathrm{NO}_{3}\right)_{2}$ of $1,100,500,3000$, and $10000 \mathrm{mg} / \mathrm{L}$. The results indicated that almost a complete removal of both ions was achieved by both minerals for the initial concentrations of 1 and $100 \mathrm{mg} / \mathrm{L}$. The adsorption data of both ions on kaolinite and clinoptilolite were examined using the Freundlich isotherm; the linearized form of which is given be:

$\log [\mathrm{C}]_{\mathrm{s}}=\log k+n \log [\mathrm{C}]_{1}$

where $[\mathrm{C}]_{\mathrm{S}}$ is the amount adsorbed, $[\mathrm{C}]_{1}$ is the equilibrium concentration of the adsorptive $(\mathrm{mg} / \mathrm{L})$, and $n$ and $k$ are the Freundlich constants. The adsorption isotherms of $\mathrm{Zn}^{2+}$ on kaolinite and clinoptilolite were reported before (Shahwan et al., 2005) and are provided here for comparison with those of $\mathrm{Pb}^{2+}$ ions. Freundlich plots are given in Fig. 1 and the values of $n$ and $k$ are provided in Table 3 . The relatively low $n$ values imply that, within the studied concentration range, increasing the initial concentration is resulting in a significant decrease in the fixation ability of the minerals. The $k$ values indicate a higher adsorption capacity of clinoptilolite compared to kaolinite towards both 

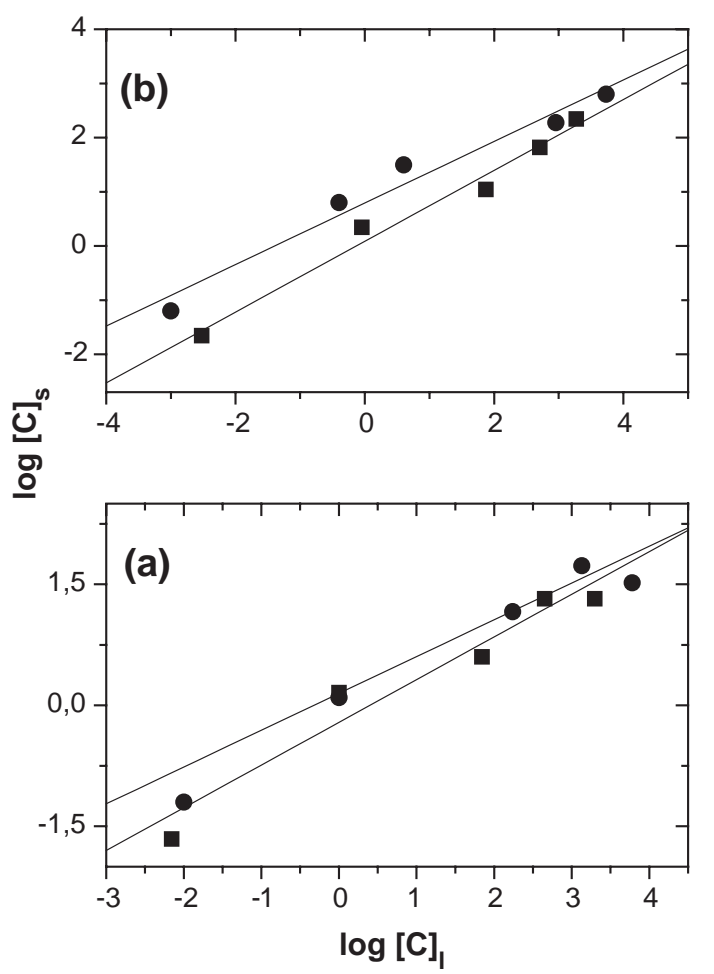

Fig. 1. Freundlich plots corresponding to the adsorption of (a) $\mathrm{Zn}^{2+}$ ions and (b) $\mathrm{Pb}^{2+}$ ions on kaolinite and clinoptilolite: (ם) kaolinite and $(\bullet)$ clinoptilolite.

ions, and reveals also higher capacity of both minerals towards $\mathrm{Pb}^{2+}$.

The XRPD and SEM characterization showed no changes in the structure and particle morphology of kaolinite and clinoptilolite upon the sorption of $\mathrm{Zn}^{2+}$ and $\mathrm{Pb}^{2+}$ by the two minerals. No surface precipitation was also detected, which was expected as a result of pH 4-8 (Table 1).

Cation exchange is the primary retention mechanism for $\mathrm{Pb}^{2+}$ by kaolinite and the speciation of this ion

Table 3

Freundlich parameters for the adsorption of $\mathrm{Zn}^{2+}$ and $\mathrm{Pb}^{2+}$ ions on kaolinite and clinoptilolite

\begin{tabular}{llll}
\hline & $n$ & $\mathrm{k}$ & $\mathrm{R}$ \\
\hline Zn-kaolinite & 0.53 & 0.62 & 0.9583 \\
Zn-clinoptilolite & 0.65 & 1.21 & 0.9908 \\
$\mathrm{~Pb}$-kaolinite & 0.46 & 1.41 & 0.9295 \\
$\mathrm{~Pb}$-clinoptilolite & 0.57 & 6.21 & 0.9849 \\
\hline
\end{tabular}

in solution could affect the selectivity of the kaolinite towards the same ion (Coles and Yong, 2002). In another study, the uptake of $\mathrm{Pb}^{2+}$ ions by kaolinite was referred to a combination of ion exchange and surface complexation, the hypothesis supported by the agreement between an ion exchange/surface complexation model and the sorption data (Holm and Zhu, 1994). In a study of $\mathrm{Pb}^{2+}$ and $\mathrm{Zn}^{2+}$ retention by kaolinite at metal concentrations of $100 \mu \mathrm{M}$, it was shown that the adsorption data were fitted closely by a constant-capacitance surface complexation model, one involving electrostatic attraction between transition metal ions and the permanent, negatively charged sites on the silanol faces of kaolinite, while the other is an inner-sphere complex at the variable-charge surface hydroxyl groups situated at the crystal edges and on the aluminol faces (Ikhsan et al., 1999). Our previous studies on the adsorption of other divalent ions $\left(\mathrm{Co}^{2+}\right.$ and $\left.\mathrm{Ba}^{2+}\right)$ by kaolinite using ToF-SIMS depth profiling have shown that the fixation of these ions is associated with a decrease in the initial amount of exchangeable cations of the kaolinite, but that the

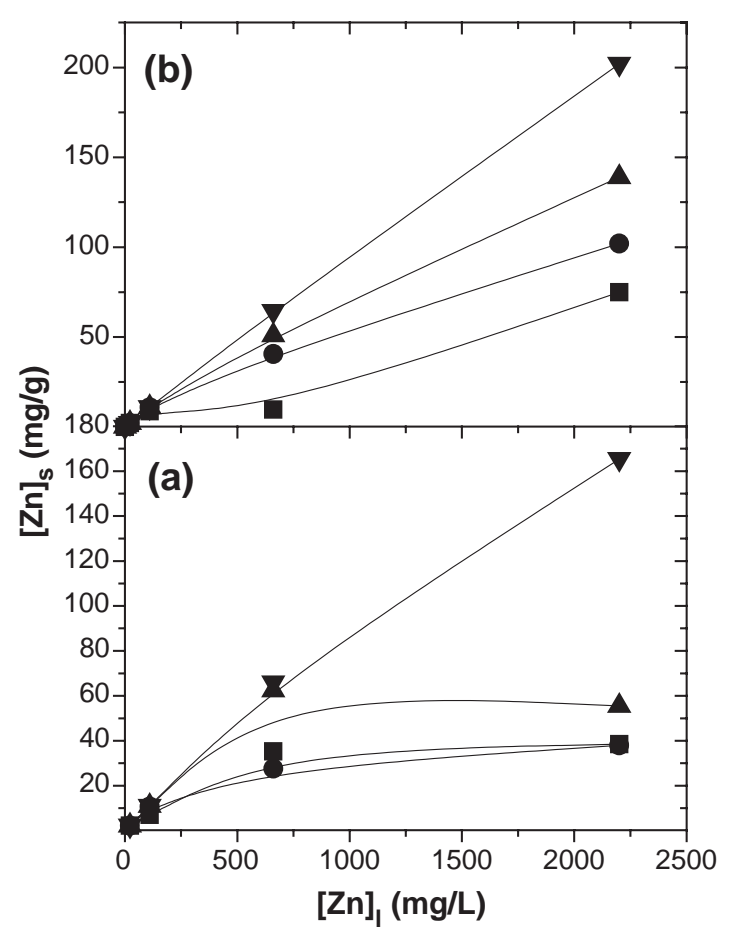

Fig. 2. Adsorption isotherms of $\mathrm{Zn}^{2+}$ ions on (a) kaolinite- $-\mathrm{MgCO}_{3}$ and (b) clinoptilolite- $\mathrm{MgCO}_{3}$ mixtures: (ロ) $5 \% \mathrm{MgCO}_{3}$, (-) $10 \%$ $\mathrm{MgCO}_{3},(\boldsymbol{\Delta}) 25 \% \mathrm{MgCO}_{3}$ and ( $) 60 \% \mathrm{MgCO}_{3}$. 


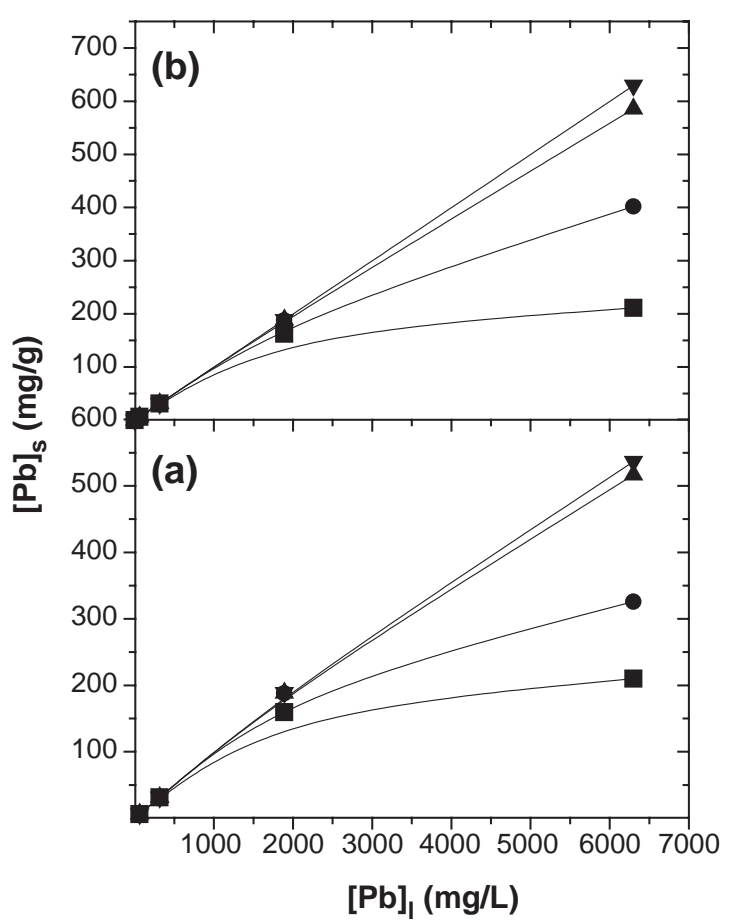

Fig. 3. Adsorption isotherms of $\mathrm{Pb}^{2+}$ ions on (a) kaolinite- $-\mathrm{MgCO}_{3}$ and (b) clinoptilolite- $\mathrm{MgCO}_{3}$ mixtures: (ロ) $5 \% \mathrm{MgCO}_{3},(\bullet) 10 \%$ $\mathrm{MgCO}_{3},(\boldsymbol{\Delta}) 25 \% \mathrm{MgCO}_{3}$ and $(\boldsymbol{\nabla}) 60 \% \mathrm{MgCO}_{3}$.

decrease did not quantitatively agree with the amount of adsorbed $\mathrm{Co}^{2+}$ or $\mathrm{Ba}^{2+}$ kaolinite (Shahwan et al., 2004). In summary, when discussing the adsorption mechanism by kaolinite, in addition to the exchange of exchangeable metal cations, protons of the $\mathrm{OH}_{2}^{+}$ and $\mathrm{OH}$ groups at the edges should also be taken into consideration. Usually the contribution of each mechanism depends on the $\mathrm{pH}$ conditions, crystallinity, and particle size of the sample (Ma and Eggleton, 1999).

Due to its porous structure that usually contains readily exchangeable ions like $\mathrm{Na}^{+}, \mathrm{K}^{+}$, and $\mathrm{Ca}^{2+}$, clinoptilolite is expected to adsorb metal ions mainly through ion exchange as reported for the adsorption of $\mathrm{Zn}^{2+}$ and $\mathrm{Pb}^{2+}$ in a number of studies (e.g. Ponizovsky and Tsadilas, 2003; Ouki and Kavannagh, 1997; Mondale et al., 1995). Higher selectivity was reported for $\mathrm{Pb}^{2+}$ by clinoptilolite compared to $\mathrm{Zn}^{2+}$ (Langella et al., 2000; Mondale et al., 1995), in line with our findings. The ion-exchange mechanism is expected to prevail unless the $\mathrm{pH}$ is high enough to allow possible precipitation of those ions as hydroxides.
High $\mathrm{pH}$ might also lead to the formation of anionic hydroxo-complexes of the metal ions, thus lowering the adsorption (Mier et al., 2001). It should be noted that different cationic compositions can lead to contrasting behavior of various clinoptilolites towards metal ions, ascribed to different characteristics of the deposits of this mineral (Langella et al., 2000). Generally, the wide variation in the cation exchange capacity of zeolites was reported to be caused by the differing nature of various zeolite cage structures, natural structural defects, adsorbed ions, and their associated gangue minerals (Mondale et al., 1995). The same study documented also a high selectivity of clinoptilolite towards $\mathrm{Pb}^{2+}$.

The amount of adsorbed $\mathrm{Zn}^{2+}$ and $\mathrm{Pb}^{2+}$ ions increases with the increasing $\mathrm{MgCO}_{3}$ in the mixtures with kaolinite and clinoptilolite (Figs. 2 and 3). In all cases, the amounts of both cations adsorbed seem to vary almost linearly with increasing equilibrium concentration - within the studied

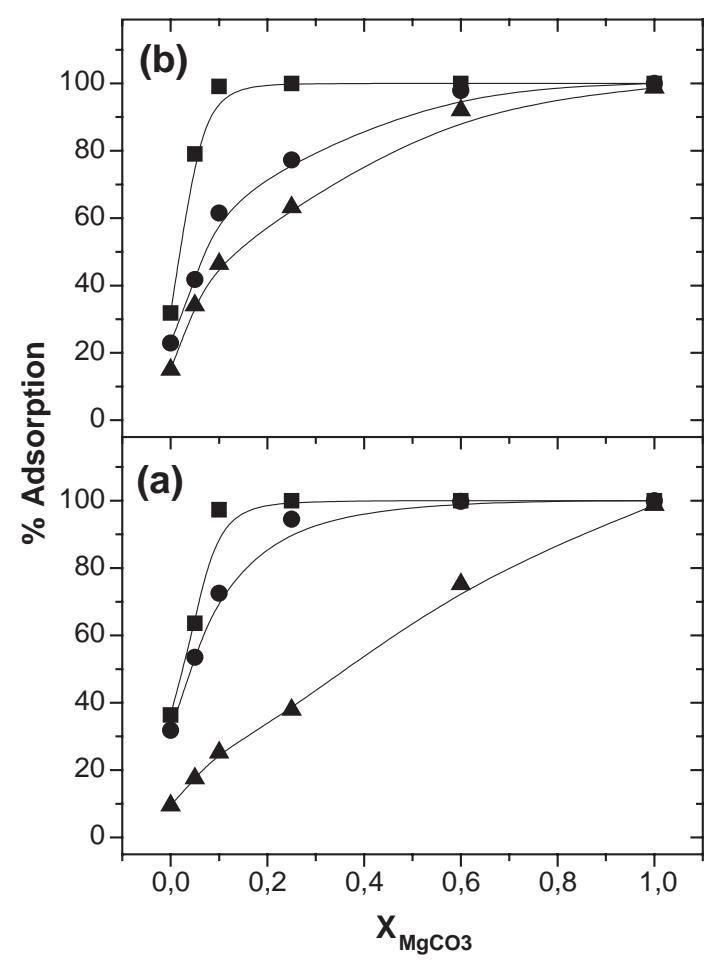

Fig. 4. Adsorption of $\mathrm{Zn}^{2+}$ ions (in percent added amounts) with the mass fraction of $\mathrm{MgCO}_{3}$ : (a) kaolinite- $\mathrm{MgCO}_{3}$ and (b) clinoptilolite- $\mathrm{MgCO}_{3}$. Initial concentrations are (ם) $500 \mathrm{mg} / \mathrm{L},(\bullet) 3000 \mathrm{mg} /$ $\mathrm{L}$, and $(\boldsymbol{\Delta}) 10000 \mathrm{mg} / \mathrm{L}$ of $\mathrm{Zn}\left(\mathrm{NO}_{3}\right)_{2}$. 


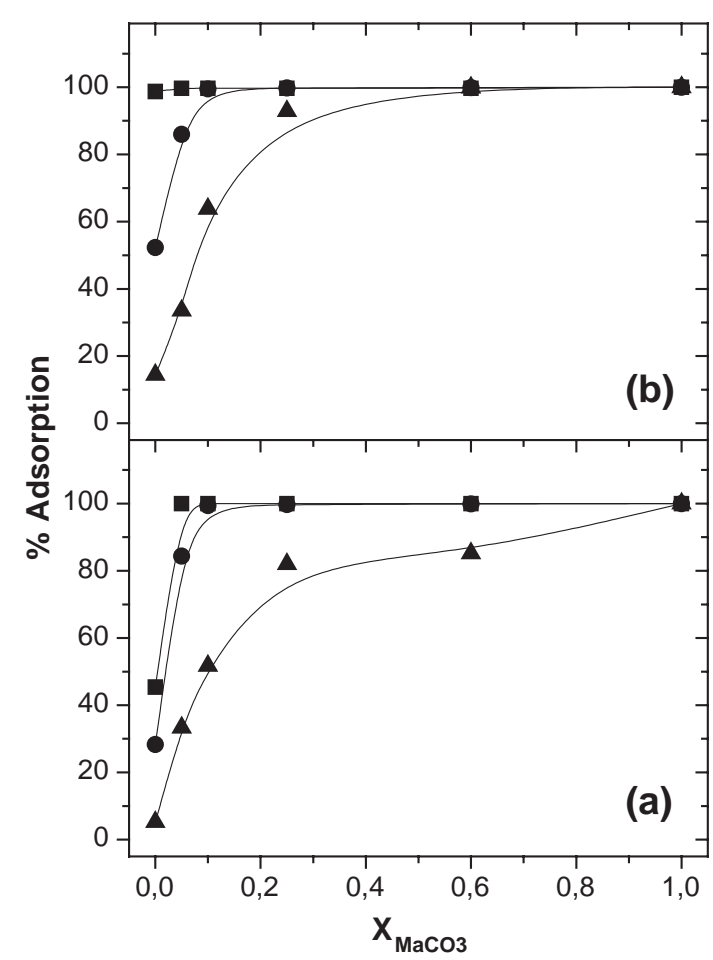

Fig. 5. Adsorption of $\mathrm{Pb}^{2+}$ (in percent added amounts) ions with the mass fraction of $\mathrm{MgCO}_{3}$ : (a) kaolinite- $\mathrm{MgCO}_{3}$ and (b) clinoptilolite- $\mathrm{MgCO}_{3}$. Initial concentrations are (ם) $500 \mathrm{mg} / \mathrm{L},(\bullet) 3000 \mathrm{mg} /$ $\mathrm{L}$, and $(\boldsymbol{\Delta}) 10000 \mathrm{mg} / \mathrm{L}$ of $\mathrm{Pb}\left(\mathrm{NO}_{3}\right)_{2}$ solutions.

range of concentrations - as the $\mathrm{MgCO}_{3}$ fraction was increased to 0.60 . The increase of the adsorption expressed in $\%$ of metal ions added is shown in Figs. 4 and 5. The figures display a large increase in the efficiency of removal of both ions as the fraction of $\mathrm{MgCO}_{3}$ in the mixtures was increased.

The XRPD analysis showed that the large increase in the amounts of $\mathrm{Zn}^{2+}$ and $\mathrm{Pb}^{2+}$ ions adsorbed by kaolinite- $\mathrm{MgCO}_{3}$ or clinoptilolite- $\mathrm{MgCO}_{3}$ at higher concentrations was associated with the precipitation of hydroxo-carbonate phases of these ions, in particular at high $\mathrm{MgCO}_{3}$ contents. The percentage uptake on $\mathrm{MgCO}_{3}$ was drawn as a function of initial concentration of $\mathrm{Zn}\left(\mathrm{NO}_{3}\right)_{2}$ and $\mathrm{Pb}\left(\mathrm{NO}_{3}\right)_{2}$ solutions (Fig. 6), which gives also the corresponding behavior of kaolinite and clinoptilolite. The efficiency of $\mathrm{MgCO}_{3}$ in the removal of both cations is more distinct at higher initial concentration, where kaolinite and clinoptilolite becomes satu- rated. XRPD analysis of $\mathrm{Zn}^{2+}-$ and $\mathrm{Pb}^{2+}$-loaded $\mathrm{MgCO}_{3}$ showed that the principal mechanism of retardation of $\mathrm{Zn}^{2+}$ and $\mathrm{Pb}^{2+}$ ions at the highest initial concentrations (3000 and $10000 \mathrm{mg} / \mathrm{L}$ ) is mainly through precipitation. At the lower initial concentration $(1,100$ and $500 \mathrm{mg} / \mathrm{L}$ ) no precipitates were detected for both ions, possibly indicating that the sorption process is dominated by ion-exchange. In addition to the enhancement of removal of ions from solution, precipitation is reported to greatly immobilize the adsorbed ions (Wang and $\mathrm{Xu}$, 2001). $\mathrm{Zn}^{2+}$-loaded $\mathrm{MgCO}_{3}$ samples revealed the formation of hydrozincite (Fig. 7a). In the presence of carbonate and hydroxide ions, zinc ions can form precipitates of the general formula $\mathrm{Zn}\left(\mathrm{CO}_{3}\right)_{x}$ $(\mathrm{OH})_{2-2 \times}$ with $0<x<1$, where $x$ is controlled by the synthesis procedure (Zhang et al., 2004). The formation of hydrozincite in our experiments is interesting because the $\mathrm{pH}$ of the medium at the initial concentrations of 3000 and $10000 \mathrm{mg} / \mathrm{L}$ (at which the precipitates occurred) was slightly acidic (Table 1). This indicates that the solubility limit is exceeded

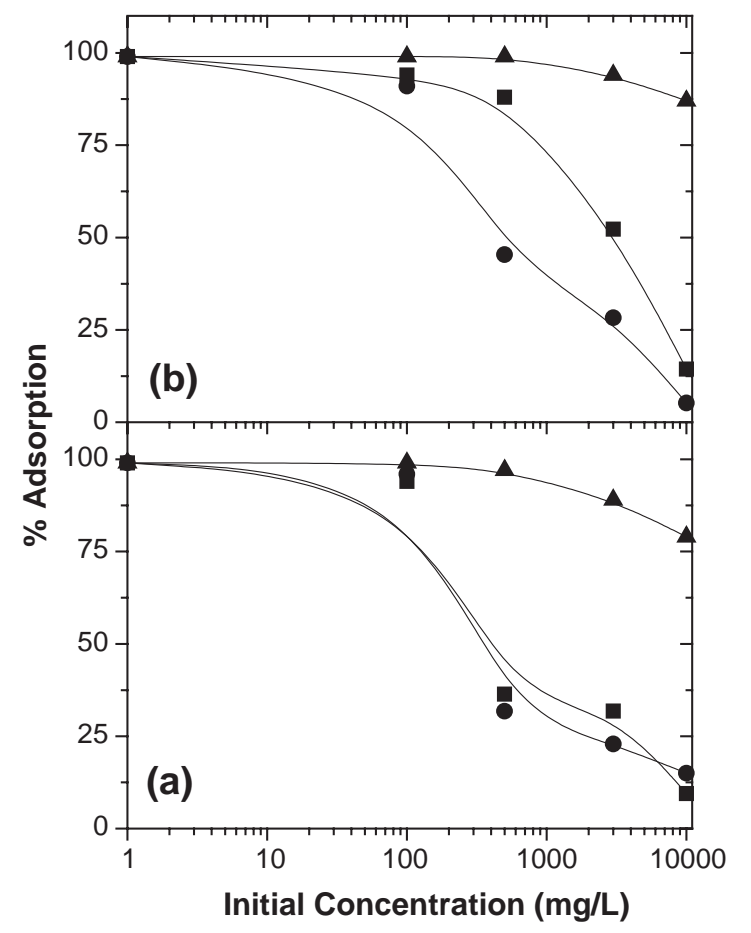

Fig. 6. Adsorption of (a) $\mathrm{Zn}$ ions and (b) $\mathrm{Pb}$ ions (in percent added amount) on kaolinite ( $)$, clinoptilolite ( $\boldsymbol{\square})$, and magnesite ( $\boldsymbol{\Delta})$ as a function of initial metal ion concentration. 

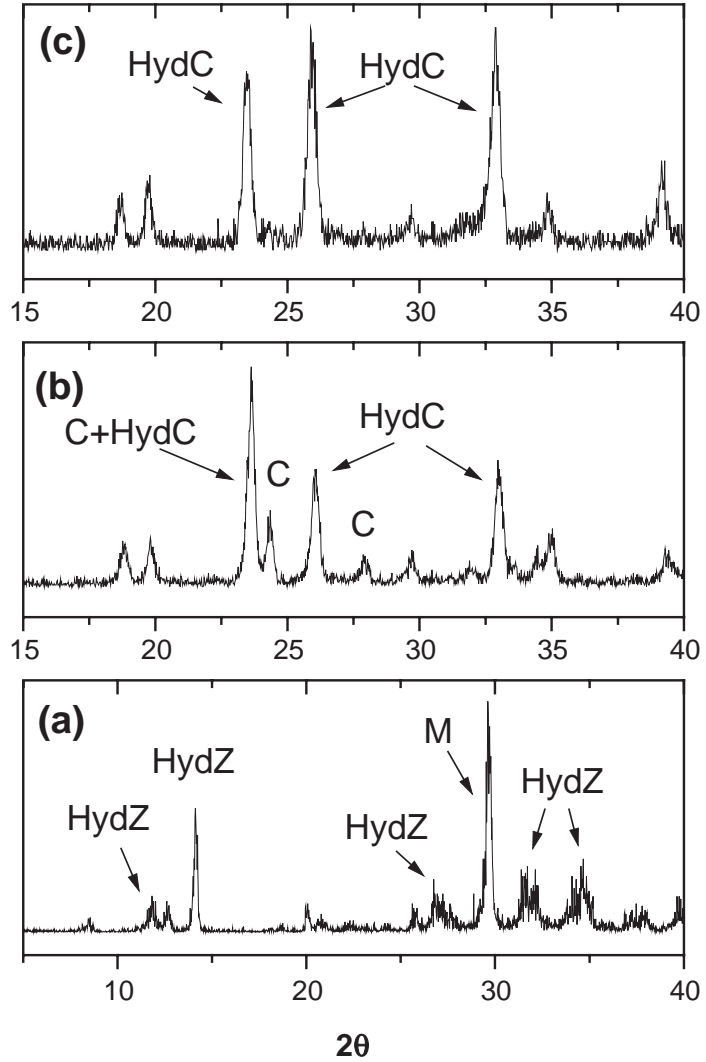

Fig. 7. XRPD patterns showing (a) hydrozincite formation on $\mathrm{MgCO}_{3}$ in the $\mathrm{pH}$ range of 6.1-6.3, (b) cerussite and hydrocerussite formation on $\mathrm{MgCO}_{3}$ in the $\mathrm{pH}$ range of 4.1-7.7 and (c) hydrocerussite formation on $\mathrm{MgCO}_{3}$ when the initial $\mathrm{pH}$ is 10 . In all cases, the initial concentration of $\mathrm{Zn}\left(\mathrm{NO}_{3}\right)_{2}$ and $\mathrm{Pb}\left(\mathrm{NO}_{3}\right)_{2}$ is 10000 $\mathrm{mg} / \mathrm{L}$. HydZ: hydrozincite; HydC: hydrocerussite; C: cerussite.

near the carbonate surface due to the accumulation of $\mathrm{Zn}^{2+}$ ions in the diffuse part of the electrical double layer, thus allowing for surface precipitation. XRPD and SEM analysis showed that increasing the initial $\mathrm{pH}$ to 10 did not change the type of precipitated species although more amount of precipitate was observed. A typical SEM image of hydrozincite is shown in Fig. 8a.

For the $\mathrm{Pb}$-loaded $\mathrm{MgCO}_{3}$ samples, Fig. $7 \mathrm{~b}$ indicates the formation of a mixture of cerussite, $\mathrm{PbCO}_{3}$, and hydrocerussite, $\mathrm{Pb}_{3}\left(\mathrm{CO}_{3}\right)_{2}(\mathrm{OH})_{2}$, in the samples that were prepared without any $\mathrm{pH}$ control. Again, the partial presence of hydrocerussite is interesting as the $\mathrm{pH}$ of the medium at the corresponding initial concentrations of $\mathrm{Pb}^{2+}$ solutions was acidic (Table

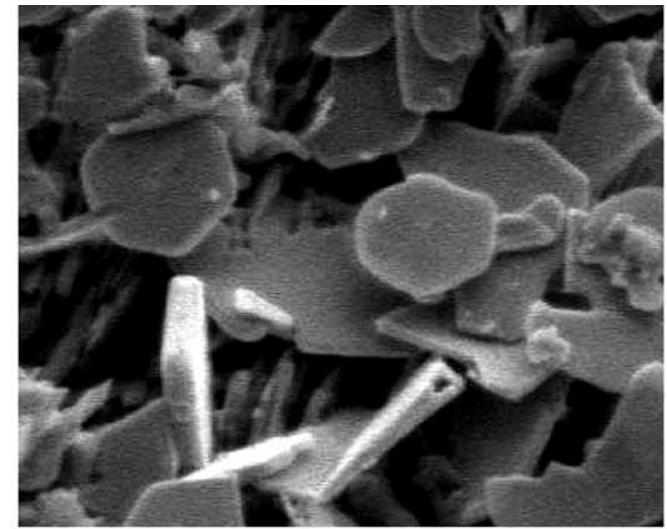

(c)

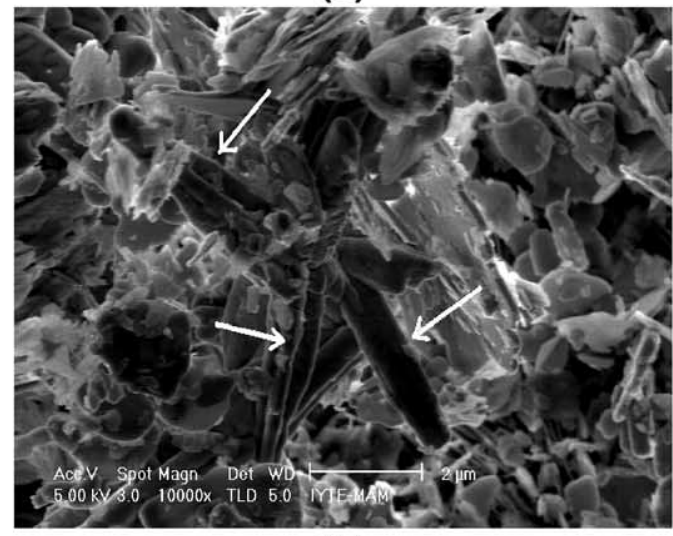

(b)

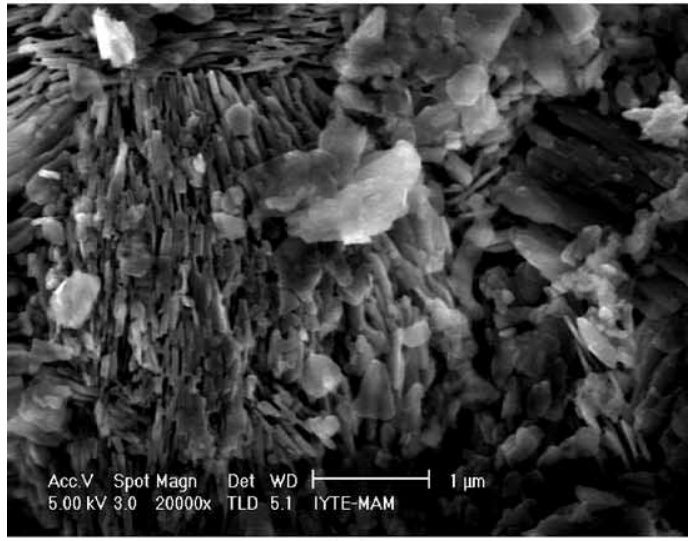

(a)

Fig. 8. Typical SEM images of (a) hydrozincite, (b) cerussite crystals embedded between crystals of hydrocerussite and $\mathrm{MgCO}_{3}$ and (c) hydrocerussite crystals. 
1). Increasing the initial $\mathrm{pH}$ to 10.0 lead to the formation of hydrocerussite only (Figs. 7c and 8c), indicating that this form is more stable at high $\mathrm{pH}$ values. SEM studies supported the XRPD observations. Cerussite crystals possess a columnar morphology (follow the arrows; approximate length of crystals is $5 \mu \mathrm{m}$; approximate width is $0.5 \mu \mathrm{m}$ ) embedded in hydrocerussite crystals. Hydrocerussite crystals have plate-like morphology with shapes close to hexagonal but with rounded edges, and edge lengths ranging from 0.5 to $2 \mu \mathrm{m}$.

Based on a linear free energy correlation model, magnesite among isostructural carbonates was reported to possess the largest partition coefficients, $K_{\mathrm{d}}$, for divalent metal ions (Wang and $\mathrm{Xu}, 2001$ ). The model, which was based on a theoretical thermodynamic approach, considered that metal ion partitioning between minerals and aqueous solution depends on the bonding energies between the fixed metal ion and the host mineral, the size difference between the fixed metal and the host cation, and the difference in chemical potential between the fixed metal cation and the host one in solution. Based on these considerations, $\log K_{\mathrm{d}}$ values of $\mathrm{Zn}^{2+}$ and $\mathrm{Pb}^{2+}$ on magnesite were predicted to be 1.97 and 4.26 , respectively. Together with stressing the importance of $\mathrm{MgCO}_{3}$ as a scavenger for metal ions, these theoretical predictions are qualitatively in agreement with our results which showed that larger amounts of $\mathrm{Pb}^{2+}$ ions are fixed by $\mathrm{MgCO}_{3}$ compared to $\mathrm{Zn}^{2+}$ (Fig. 6).

\section{Conclusions}

The adsorption of $\mathrm{Zn}^{2+}$ and $\mathrm{Pb}^{2+}$ ions on kaolinite and clinoptilolite is fast and obeys the Freundlich isotherm model. The affinity of both minerals towards $\mathrm{Pb}^{2+}$ ions is generally larger than towards $\mathrm{Zn}^{2+}$ ions. Within the studied concentration range and $\mathrm{pH}$ conditions, the presence of $\mathrm{MgCO}_{3}$ increased the adsorption of $\mathrm{Zn}^{2+}$ and $\mathrm{Pb}^{2+}$ ions. The large increase in the amounts of $\mathrm{Zn}^{2+}$ and $\mathrm{Pb}^{2+}$ ions adsorbed with the increasing fraction of $\mathrm{MgCO}_{3}$ reveals that $\mathrm{MgCO}_{3}$ is a more favorable sink for these ions and demonstrates the higher uptake capacity of this mineral compared to kaolinite and clinoptilolite. At higher fractions of $\mathrm{MgCO}_{3}$ and higher equilibrium concentrations, pre- cipitation of hydroxo-carbonates enhances the removal of both ions from the aqueous solutions.

\section{Acknowledgement}

We would like to acknowledge İzmir Institute of Technology for support of this work through the fund 2003 IYTE 03. The authors would also like to thank the Center of Material's Research at IZTECH for their help in the XRPD and SEM/EDS measurements and Dr. Fehime Özkan for her help in the surface-area analysis.

\section{References}

Caussy, D., Gochfeld, M., Gurzau, E., Neagu, C., Ruedel, H., 2003. Lessons from case studies of metals: investigating exposure, bioavailability and risk. Ecotoxicol. Environ. Saf. 25, 45-51.

Coles, C.A., Yong, R.N., 2002. Aspects of kaolinite characterization and retention of $\mathrm{Pb}$ and $\mathrm{Cd}$. Appl. Clay Sci. 22, 39-45.

Godelitsas, A., Astilleros, J.M., Hallam, K., Harissopoulos, S., Putnis, A., 2003. Interaction of calcium carbonates with lead in aqueous solutions. Environ. Sci. Technol. 37 (15), 3351-3360.

Holm, T.R., Zhu, X., 1994. Sorption by kaolinite of $\mathrm{Cd}^{2+}, \mathrm{Pb}^{2+}$ and $\mathrm{Cu}^{2+}$ from landfill leachate-contaminated groundwater. J. Contam. Hydrol. 16, 271-287.

Hooda, P.S., Alloway, B.J., 1998. Cadmium and lead sorption behaviour of selected English and Indian soils. Geoderma 84, $121-134$.

Ikhsan, J., Johnson, B.B., Wells, J.D., 1999. A comparative study of the adsorption of transition metals on kaolinite. J. Colloid Interface Sci. 217, 403.

Langella, A., Pansini, M., Cappelletti, P., de Gennaro, B., de' Gennaro, M., Colella, C., 2000. $\mathrm{NH}_{4}^{+}, \mathrm{Cu}^{2+}, \mathrm{Zn}^{2+}, \mathrm{Cd}^{2+}$ and $\mathrm{Pb}^{2+}$ exchange for $\mathrm{Na}^{+}$in a sedimentary clinoptilolite, North Sardinia, Italy. Microporous Mesoporous Mater. 37, 337-343.

Lehmann, M., Zouboulis, A.I., Matis, K.A., 1999. Removal of metal Ions from dilute aqueous solutions: a comparative study of inorganic sorbent materials. Chemosphere 39, 881-892.

Ma, C., Eggleton, R.A., 1999. Cation exchange capacity of kaolinite. Clay Miner. 47, 174-180.

Mier, M.V., Callejas, R.L., Gehr, R., Cisneros, B.E.J., Alvarez, P.J.J., 2001. Heavy metal removal with Mexican clinoptilolite: multi-component ionic exchange. Water Res. 35, 373-378.

Miranda-Trevino, J.C., Coles, C.A., 2003. Kaolinite properties, structure and influence of metal retention on $\mathrm{pH}$. Appl. Clay Sci. 23, 133-139.

Mondale, K.D., Carland, R.M., Aplan, F.F., 1995. The comparative ion exchange capacities of natural sedimentary and synthetic zeolites. Miner. Eng. 8, 535-548.

Nachtegaal, M., Sparks, D.L., 2004. Effect of iron oxide coatings on zinc sorption mechanisms at the clay-mineral/water interface. J. Colloid Interface Sci. 276, 13-23. 
Nour El-Dien, F.A., Ali, M.M., Zayed, M.A., 1997. Thermodynamic study for the $\left(\mathrm{NH}_{4}^{+}-\mathrm{K}^{+}\right)$exchange on $\mathrm{K}$-saturated clinoptilolite. Thermochim. Acta 307, 65-75.

Ouki, S.K., Kavannagh, M., 1997. Performance of natural zeolites for the treatment of mixed metal-contaminated effluents. Waste Manage. Res. 15, 383-394.

Pierrard, J.C., Rimbault, J., Aplincourt, M., 2002. Experimental study and modelling of lead solubility as a function of $\mathrm{pH}$ in mixtures of ground waters and cement waters. Water Res. 36, 879-890.

Ponizovsky, A.A., Tsadilas, C.D., 2003. Lead(II) retention by Alfisol and clinoptilolite: cation balance and $\mathrm{pH}$ effect. Geoderma $115,303-312$.

Shahwan, T., Atesin, A.C., Erten, H.N., Zararsiz, A., 2002. The uptake of $\mathrm{Ba}^{2+}$ ions by natural bentonite and $\mathrm{CaCO}_{3}$ : a radiotracer, EDXRF and PXRD study. J. Radioanal. Nucl. Chem. 254/3, 563

Shahwan, T., Erten, H.N., Black, L., Allen, G.C., 2004. ToF-SIMS depth profiling analysis of the uptake of $\mathrm{Ba}^{2+}$ and $\mathrm{Co}^{2+}$ ions by natural kaolinite clay. J. Colloid Interface Sci. 277, 23-28.
Shahwan, T., Zünbül, B., Tunusoğlu, Ö., Eroğlu, A.E., 2005. AAS, XRPD, SEM/EDS, and FTIR Characterization of $\mathrm{Zn}^{2+}$ retention by calcite, calcite-kaolinite, and calcite-clinoptilolite minerals. J. Colloid Interface Sci. 286, 471-478.

Tanaka, H., Yamasaki, N., Muratani, M., Hino, R., 2003. Structure and formation process of $(\mathrm{KNa})$-clinoptilolite. Mater. Res. Bull. $38,713-722$.

Wang, Y., Xu, H., 2001. Prediction of trace metal partitioning between minerals and aqueous solutions: a linear free energy correlation approach. Geochim. Cosmochim. Acta 65, $1529-1543$

Wenming, D., Zhijun, G., Jinzhou, D., Liying, Z., Zuyi, T., 2001. Sorption characteristics of zinc(II) by calcareous soil-radiotracer study. Appl. Radiat. Isotopes 54, 371-375.

Zhang, S., Fortier, H., Dahn, J.R., 2004. Characterization of zinc carbonate hydroxides synthesized by precipitation from zinc acetate and potassium carbonate solutions. Mater. Res. Bull. $39,1939-1948$. 